\title{
Supervision anxiety as a predictor for organizational cynicism in teachers
}

\author{
Hasan Basri Gündüz ${ }^{1}$ \\ Yunus Emre Ömür ${ }^{2}$
}

\begin{abstract}
The purpose of this is study is to reveal how the anxiety that the teachers who work in the Beyoğlu district of Istanbul experience, due to the supervision process, predict their organizational cynicism levels. With this respect, the study was conducted on 274 teachers with the relational screening model. The "Supervision Anxiety Scale" and the "Organizational Cynicism Scale" were used to collect the data. The SPSS 22.0 software was used to analyze the data and arithmetic mean, standard deviation, Pearson Product-Moment Correlation Analysis and regression analyses were conducted. According to the study findings, there is a positive, moderate level and statistically significant level relationship between supervision anxiety and organizational cynicism levels of teachers. The regression analysis results suggest that supervision anxiety of teachers is a significant predictor of their organizational cynicism levels.
\end{abstract}

Keywords: Organizational Cynicism; Supervision Anxiety; Teacher Anxiety; Teacher Supervision; Supervision.

\section{Introduction}

One of the most important functions of educational systems is to raise a nation's human power with skills required by national and global economic system. This is valid for both developing and developed countries because development and sustaining development are succeeded not only economically, but also raising quality human power (Karakütük, 2012). This quality is only achieved by means of quality education. In this context, teachers' environment and their attitudes towards their organizations should be regarded as basis of quality education. Because it is thought teachers working in hard environments and having negative attitudes towards their schools will not be beneficial to their students.

Based on this idea, the aim of this study is to investigate teachers' negative attitudes towards their organizations, which is called organizational cynicism, and anxiety they feel during supervision process. The relationship between these two phenomenon is also investigated within scope of this study. Although it is known in the related literature that anxiety teachers feel causes organizational

\footnotetext{
1 Associated Professor, Yildiz Technical University, Faculty of Education, Department of Educational Sciences, hgundus@gmail.com

2 Research Assistant, Yildiz Technical University, Faculty of Education, Department of Educational Sciences, yunus.emre.omur@gmail.com
} 
Gündüz, H. B., \& Ömür, Y. E. (2016). Supervision anxiety as a predictor for organizational cynism in teachers. International Journal of Human Sciences, 13(1), 1381-1394. doi:10.14687/ijhs.v13i1.3626

cynicism, an empirical study is needed to reveal the relationship between supervision anxiety and organizational cynicism. Thus this study was conducted to satisfy this need in the literature.

\section{Organizational Cynicism}

Cynicism, which was a school of ancient Greek philosophy, reached its shinning era with Antisthenes, who had been a pupil of Socrates during 3rd and 4th centuries BC (Dean, Brandes, Dharwadkar, 1998). Antisthenes, who was thinking about what happiness is and how one can achieve it, claimed that virtue is equal to being wise and that happiness can only be possible with virtue (Hançerlioğlu, 1999). Thus, he believed that the human could turn into a stronger being through every kind of sacrifice that a virtuous life would require (Gökberk, 2000).

Today the word cynicism bears a very different meaning and is defined as being averse to others, having distrust to others, feeling hopeless, being frustrated and being disappointed (Abraham, 2000; Brandes et al., 2008). When the definitions of cynicism in the literature are considered, Bernerth, Armenakis, Field and Walker (2007) define cynicism as the belief that principles such as rightness, honesty and sincerity are exploited for the benefit of organizational interest and that humans and their institutional organizations lack moral integrity. Tokgöz and Yllmaz (2008) define cynicism as, "peoples attitude of explaining secret and unspoken aims in a pessimist manner and explaining events in a disappointed manner; the tendency to care for others and handle situations as a tool for increasing and protecting one's own interests". In another definition, Anderson (1996) states that cynicism is "both a general and specific attitude like frustration, hopelessness and disappointment and also negative feelings and distrust towards a person, a group, an ideology, a social custom or institutions".

When considered as an organizational behavior, cynicism can be said to be negative attitudes and beliefs one develops against the organization he or she works in due to various reasons. Dean, Brandes and Dharwadkar (1998) define organizational cynicism as negative attitudes that one displays against the organization. While Wanous, Reichers and Austine (2000) explain organizational cynicism as the pessimist point of view that organizations develop against the effort and labor of the changes they made in order to succeed; Helvacı and Çetin (2012) define cynicism as workers having a disbelief for organization decision, having distrust for their intentions and believing that the administrators do not show their true selves. Similarly, according to Turner and Valentine (2001), cynicism is both a general and a specific dimension for making a moral decision which considers the strengths of distrust, being skeptical in a hostile way and defaming other people's urges.

Dean, Brandes and Dharwadkar (1998) underline that organizational cynicism has the following three dimensions: (1) belief that the organization lacks integrity, (2) negative feelings for the organization and (3) derogatory and critical behaviors the individual displays against the organization. In other words organizational cynicism is present in individuals in the belief dimension, the emotional dimension and behavior dimension. In the belief dimension, individuals believe that the practices and beliefs within an organization lack some values such as a justice and sincerity and as a result they believe that the organizational bodies betray them (Dean, Brandes and Dharwadkar, 1998; Urbany, 2005). In the emotional dimension of cynicism, individuals display emotional reactions such as tension, shyness, anger, disappointment, pessimism, embarrassment, losing respect and paranoia and in fact, it is stated that individuals with high cynicism levels can give such emotional reactions even when they think about the organization (Andersson and Bateman, 1997; Abraham, 2000; Pelletier and Bligh, 2008; Kutanis and Dikili, 2010). In the other dimension of cynicism, behavioral responses become evident with behaviors such as when workers express that the organization lacks sincerity and justice, when they look down on the organization and 
Gündüz, H. B., \& Ömür, Y. E. (2016). Supervision anxiety as a predictor for organizational cynism in teachers. International Journal of Human Sciences, 13(1), 1381-1394. doi:10.14687/ijhs.v13i1.3626

when they make pessimist predictions about the organization (Dean, Brandes and Dharwadkar, 1998).

\section{Supervision Anxiety in Teachers}

The role of the teacher is crucial for the quality of education within an educational system and it can be asserted that the teacher is among the main factors that are the determinants of the quality of education. In other words, succeeding in reaching a qualified education depends on many factors along with comfortable, peaceful and stress free teachers (Akpinar, 2008). Thus, in order to promote a qualified education, it is crucial for teachers to be socially, mentally, physically and emotionally in a healthy state and, along with factors like job satisfaction, a good education is possible when teachers are distant from anxiety and tension (Dubey, 2011). The stress that teachers undergo is defined as the experience of negative emotions such as anger, tension, burnout and depression due to their profession (Kyrizcou, 2001). Schulze and Steyn (2007) found that lack of learner motivation, poor learner discipline, uninvolved parents, learners' negative attitudes towards themselves, numerous changes inside and outside the school, and lack of self-esteem are main teacher stressors in schools. There are also experimental studies that have put forward that teachers working in an anxious and stressful way is a factor that not only affects them but also the anxiety levels of their students. Because the working conditions of teachers also constitutes the learning conditions of students (Younghusband, 2006). For example Sinclair and Ryan (1987) have stated that when teachers enter the lecture in a stressful way, this will affect the stress levels of the students and that stressful teachers are perceived as insufficient by students. Similarly, Beilock, Gunderson, Ramirez and Levine (2010) asserted that the anxiety that female mathematics teachers experience increases female students' anxiety levels.

When the related literature is examined, it is obvious that there are various reasons for the anxiety and stress that teachers undergo. Among the main reasons for the stress that teachers suffer from are teachers being unable to fully execute their abilities, having to do extra work to gain more income, lack of time to give feedback to the activities that students carry out, the school principle not being promotive, lack of motivation in students, student-teacher communication problems, time pressure, discipline problems, low wage and low social status, bad working conditions, work overload, lack of promotion opportunities, administrative problems, role conflict and uncertainty, changes in the educational system, school culture, being evaluated by others and the supervision system (Akpinar, 2008; Dubey, 2011; Kyriacou, 2001; McCormick and Solman, 1992).

Accountability and standardization, which have been on the public services agenda recently, are also present in the education field. Thus, in many countries, the main reason for students succeeding in many standard tests is due to the accountability of teachers and this is promoted by the supervision mechanism. The most outstanding reform made in developed countries is the Education Reform Act recognized in England in 1980 and the most prominent example the No Child Left Behind reform in the USA For example, Jeffrey and Woods (1996) stated that the supervisions that were carried out in England after the subject act were perceived by teachers as an attack against human values and led to traumas in teachers. In other words, the supervisions carried out under the context of accountability cause major stress in teachers (Botwinik, 2007). Thus, it can be said that the roles of the supervisors and the relationship between supervised-supervisor are crucial elements in the stress that teachers go through due to supervision. It is known that supervisors, who are substantial components of the educational system, have roles such as management, leadership, student, counselor, research experts and investigating magistrate (Taymaz, 2012). When these roles are considered, educational supervision is a creative power, a source of inspiration, a promotive mechanism to increase motivation and a leadership basis for education; and the ultimate goal of supervision is to furnish teachers so that they can professionally guide 
Gündüz, H. B., \& Ömür, Y. E. (2016). Supervision anxiety as a predictor for organizational cynism in teachers. International Journal of Human Sciences, 13(1), 1381-1394. doi:10.14687/ijhs.v13i1.3626

themselves (Bursalığlu, 2012). On the other hand, in order for the supervision process to be effective the supervisor should be able to perform the required attitude and the supervisor role during the supervision. Although the supervision process is seen as a mutual relationship between the supervisor and the supervised, due to their authority position, the attitudes, skills and talents of the supervisors are determinants of the processes effectiveness (Caspi and Reid, 2002). It is possible to relate the anxiety that the supervision process causes on teachers with the investigator role of supervisors. When the roles of supervisors are considered, while it is obvious that the counselor role contradicts with the investigator role, which leads supervisors to act like a "prosecutor", the most effective role mastered in Turkey is the investigating role (Altındağ, 2007; Gündüz and Göker, 2014). When it is considered together with the counselor role, the investigator role of supervisors becomes more prominent because it can directly and negatively affect the professional life of teachers. In other words, although the investigating magistrate should be the least performed competency, in practice it has become the most widespread competency area (Atay, 1995). Wilcox and Gray (1996) state that teachers find inspections as a source of anxiety and stress. In the similar studies they conducted, Durmaz (2010) stated that teachers have negative attitudes towards the supervision process; Altındağ (2007) stated that when supervisors visit the school for inspection, this causes an atmosphere of tension in the school and these results support the study findings.

As Bilir (1992) states, because the inspection sub-system of the Turkish National Education is control and investigation oriented, a classical understanding of supervision is prevalent. In this case, supervision is limited to only the investigation operations the counseling and nurturing functions of supervision are ignored (Bülbül and Acar, 2012) It can also be said that the investigation role, which is the most frequently mastered competency area of supervisors, contradicts with the educator role of supervisors (Özmen and Şahin, 2010). It won’t be wrong to claim that the actual competency that supervisors should display is in the field of counseling and nurturing teachers. However, although supervisors share the same opinion with regards to their roles, it is known that in practice their investigating role becomes prominent due to the organization of the educational system (Bülbül and Acar, 2012). It is believed that this has several negative reflections on teachers who are the supervised agents in the supervision process. Teachers can display negative emotions and attitudes towards the institution they work in as a result of the anxiety and stress that a investigation-based supervision causes. Although there are many reasons for these attitudes that are defined as organizational cynicism, one reason is the anxiety that the individual experiences in the institution he or she works in. From this point of view, the study problem reveals to what extent the anxiety that teachers undergo, due to the supervision process, predicts their level of organizational cynicism.

\section{Purpose of the Study}

The purpose of this study is to determine the level of supervision anxiety and the level of organizational cynicism of teachers who work in public schools in the Beyoğlu district of Istanbul during the 2013-2014 academic period and identify whether there is a significant relationship between the two variables or not. With this respect, the following sub-problems were asked;

1. What is the level of supervision anxiety and organizational cynicism of teachers?

2. Is there a significant relationship between the anxiety levels of teachers regarding supervision and their organizational cynicism levels?

3. Do anxiety levels of teachers regarding supervision predict their organizational cynicism levels? 
Gündüz, H. B., \& Ömür, Y. E. (2016). Supervision anxiety as a predictor for organizational cynism in teachers. International Journal of Human Sciences, 13(1), 1381-1394. doi:10.14687/ijhs.v13i1.3626

\section{Method}

\section{Research Model}

Relational screening model is used in the study. While in the screening models the event, individual or the object is defined according to its own conditions and in its present state (Karasar, 2002), relational studies are researches in which the relationship between two or more variables is examined without interfering with the variables (Büyüköztürk et al., 2012) The relationship between supervision anxiety and organizational cynicism levels of teachers was determined with this study which was carried out according to this direction.

\section{Population and Sample}

The population of the study consisted of 1034 teachers working in public schools in the Beyoğlu district of Istanbul during the 2013-2014 academic period. Because not every teacher was accessible, the sampling method was resorted to in the study and a simple, random sampling was carried out. With this respect, the study was conducted on 274 teachers. According to Cohen, Manion and Morrison (2007), a sample of 274 participants is enough for a population of 1100 individuals.

\section{Data Collection Instruments}

The "Supervision Anxiety Scale" and the "Organizational Cynicism Scale" were used to collect the data.

Supervision Anxiety Scale, developed by Karakaya, Elma, Kurtoğlu and Suiçmez (2011), consists of 30 items and 4 sub-dimensions. Because the initial form of the dimensions were not titled, the scale dimensions were named during this study according to the items in the dimensions. Thus, the I. sub-dimension was named as 'general supervision anxiety', the II. sub-dimension was 'physical effects', the III. sub-dimension was 'supervisor behaviors' and the IV. was 'factors decreasing anxiety'. The scale, whose Cronbach Alpha internal consistency was .93, is a 5 point Likert scale scored as (1) I Totally Disagree, (2) I Disagree, (3) I'm Not Sure, (4) I Agree and (5) I Totally Agree. The scales Cronbach Alpha internal consistency coefficient for this study was .93.

One other data collection instrument for the scale was the Organizational Cynicism Scale. This scale, which was developed by Sağır and Oğuz (2012), consists of 25 items and 4 sub-dimensions. These sub-dimensions were defined as 'withdrawal from the institution', 'factors decreasing performance', 'negative attitude towards the school' and 'worker participation in implementing decisions'. The scale, whose Cronbach Alpha internal consistency was .89, is a 5 point Likert scale scored as (1) I Totally Disagree, (2) I Disagree, (3) I'm Not Sure, (4) I Agree and (5) I Totally Agree. The Cronbach Alpha internal consistency coefficient of the scale for this study was .86 .

\section{Data Analysis and Interpretation}

The Statistical Package for Social Sciences (SPSS) 22.0 software was used for analyzing the study data. In analyzing the data, along with the arithmetic mean and standard deviation analyses Pearson Product-Moment Correlation, Simple Linear Regression and Multilinear Regression analyses were conducted according to the sub-dimensions. The level of significance was accepted as .05 for the significance test. In the Pearson Product-Moment Correlation analysis, .00-.30 r value indicates a low level, .30-.70 r value indicates a moderate level and .70-.100 r value indicates a high level of relationship (Büyüköztürk, Çokluk Bökeoğlu and Köklü, 2008). The score intervals on Table 1 were used in interpreting the scores obtained from the scales. 
Gündüz, H. B., \& Ömür, Y. E. (2016). Supervision anxiety as a predictor for organizational cynism in teachers. International Journal of Human Sciences, 13(1), 1381-1394. doi:10.14687/ijhs.v13i1.3626

Table 1: Score intervals used in interpreting the options listed in the scales

\begin{tabular}{ccc}
\hline Given Score & Options & Score Interval \\
\hline 1 & I Totally Disagree & $1.00-1.80$ \\
2 & I Disagree & $1.81-2.60$ \\
3 & I'm Not Sure & $2.61-3.40$ \\
4 & I Agree & $3.41-4.20$ \\
5 & I Totally Agree & $4.21-5.00$ \\
\hline
\end{tabular}

\section{Findings}

\section{Findings Regarding the First Sub-Problem}

Findings regarding the score averages and standard deviations that the teachers received from the overall and sub-dimensions of the supervision anxiety scale are presented in Table 2.

Table 2: Anxiety levels of teachers regarding supervision

\begin{tabular}{lccc}
\hline Scale & $\mathrm{n}$ & $\overline{\mathrm{X}}$ & ss \\
\hline General supervision anxiety & 274 & 3.14 & .88 \\
Physical effects & 274 & 2.22 & .90 \\
Supervisor behaviors & 274 & 3.69 & .97 \\
Factors decreasing anxiety & 274 & 3.71 & .95 \\
Total supervision anxiety & 274 & 3.08 & .69 \\
\hline
\end{tabular}

It is evident on Table 2 that supervision anxiety levels of teachers who participated in the study are at a 'I'm Not Sure' level with a $\bar{X}=3.08$ mean score for the overall scale. Scores that teachers obtained from the sub-dimensions of the supervision anxiety scale were examined and their mean score for the general supervision anxiety dimension was $\bar{X}=3.14$ as 'I'm Not Sure', their mean score for the physical effects dimension was $\bar{X}=2.22$ as 'I Disagree', their mean score for the supervisor behaviors dimension was $\overline{\mathrm{X}}=3.69$ as 'I Agree' and their mean score for the factors decreasing anxiety dimension was $\overline{\mathrm{X}}=3.71$ as 'I Agree'.

The mean and standard deviation scores that the teachers who participated in the study obtained from the overall and sub-dimensions of the organizational cynicism scale are given in Table 3.

Table 3: Organizational Cynicism Levels of Teachers

\begin{tabular}{lccc}
\hline Scale & $\mathrm{n}$ & $\overline{\mathrm{X}}$ & $\mathrm{ss}$ \\
\hline Withdrawal from the institution & 274 & 2.62 & .77 \\
Factors decreasing performance & 274 & 3.18 & 96 \\
Negative attitude towards the school & 274 & 1.99 & .89 \\
Participation in implementing decisions & 274 & 3.78 & .81 \\
Total organizational cynicism & 274 & 2.88 & .69 \\
\hline
\end{tabular}

When organizational cynicism levels of teachers are examined in the table, it is obvious that the mean score is $\overline{\mathrm{X}}=2.88$ as 'I'm Not Sure' level. According to the arithmetic means of the organizational cynism scale sub-dimensions, mean score for the withdrawal from the institution dimension was $\overline{\mathrm{X}}=2.62$ as 'I'm Not Sure', $\overline{\mathrm{X}}=3.18$ as 'I'm Not Sure' for the factors decreasing performance dimension, $\overline{\mathrm{X}}=1.99$ as 'I Disagree' for the negative attitude towards the school dimension and $\overline{\mathrm{X}}=3.78$ as 'I Agree' for the participation in implementing decisions dimension. 
Gündüz, H. B., \& Ömür, Y. E. (2016). Supervision anxiety as a predictor for organizational cynism in teachers. International Journal of Human Sciences, 13(1), 1381-1394. doi:10.14687/ijhs.v13i1.3626

\section{Findings Regarding the Second Sub-Problem}

Results of the Pearson Product-Moment Correlation analysis conducted to examine the relationship between supervision anxiety levels and organizational cynicism levels of teachers are given in Table 4.

Table 4: Results of the Pearson Product-Moment Correlation analysis regarding the relationship between supervision anxiety levels and organizational cynicism levels of teachers

\begin{tabular}{lccccc}
\hline & $\begin{array}{c}\text { Withdrawal } \\
\text { from the } \\
\text { institution }\end{array}$ & $\begin{array}{c}\text { Factors } \\
\text { decreasing } \\
\text { performance }\end{array}$ & $\begin{array}{c}\text { Negative } \\
\text { attitude } \\
\text { towards } \\
\text { the } \\
\text { school }\end{array}$ & $\begin{array}{c}\text { Worker } \\
\text { participation in } \\
\text { implementing } \\
\text { decisions }\end{array}$ & $\begin{array}{c}\text { Total } \\
\text { Organizational } \\
\text { Cynicism }\end{array}$ \\
\hline General supervision anxiety & $.246^{*}$ & $.301^{*}$ & .148 & .093 & $.321^{*}$ \\
Physical effects & $.223^{*}$ & $.172^{*}$ & $.338^{*}$ & .052 & $.288^{*}$ \\
Supervisor behaviors & $.174^{*}$ & $.244^{*}$ & $.063^{*}$ & $.265^{*}$ & $.280^{*}$ \\
Factors decreasing anxiety & .113 & $.219^{*}$ & .024 & .059 & $.191^{*}$ \\
Total supervision anxiety & $.278^{*}$ & $.327^{*}$ & .217 & .154 & $.384^{*}$ \\
\hline
\end{tabular}

$* \mathrm{p}<.05$

According to the Pearson Product-Moment Correlation Analysis results given on Table 4, there is a positive, moderate level and statistically significant relationship between the supervision anxiety levels and organizational cynicism levels of teachers $(\mathrm{r}=.384, \mathrm{p}<.01)$.

\section{Findings Regarding the Third Sub-Problem}

Results of the Simple Linear Regression Analysis, conducted to determine to what extent supervision anxiety levels of teachers predict their organizational cynicism levels, are presented on Table 5.

Table 5: Results of the Multilinear Regression Analysis regarding supervision anxiety levels of teachers predicting the overall scores of their organizational cynicism levels

\begin{tabular}{|c|c|c|c|c|c|c|c|}
\hline Model & B & Standardized $\beta$ & Standard Error & $\mathrm{F}$ & $\mathrm{R}$ & $\mathrm{R}^{2}$ & $\mathrm{p}$ \\
\hline $\begin{array}{l}\text { General supervision } \\
\text { anxiety }\end{array}$ & -220 & -.321 & .424 & & & & \\
\hline Physical effects & -.113 & -.167 & .290 & & & & \\
\hline Supervisor behaviors & -.079 & -.125 & .213 & 9.402 & .386 & .149 & $.000^{*}$ \\
\hline $\begin{array}{l}\text { Factors decreasing } \\
\text { anxiety }\end{array}$ & -.061 & -.094 & .149 & & & & \\
\hline Total Scale & .811 & 921 & 1.051 & & & & \\
\hline
\end{tabular}

$* \mathrm{p}<.05$

According to the multi-linear regression analysis results on Table 5, there is a significant relationship between the sub-dimensions of the supervision anxiety scale and total scale scores along with organizational cynicism levels of teachers $\left(\mathrm{R}=.386, \mathrm{R}^{2}=.0000\right)$ and that the subdimensions are significant predictors of teachers withdrawing from the institution they work in $(\mathrm{F}=$ 9.402, $\mathrm{p}<.05)$. These variables explain $15 \%$ of the change in the organizational cynicism levels of teachers. 
Gündüz, H. B., \& Ömür, Y. E. (2016). Supervision anxiety as a predictor for organizational cynism in teachers. International Journal of Human Sciences, 13(1), 1381-1394. doi:10.14687/ijhs.v13i1.3626

Results of the Multilinear Regression Analysis regarding the level of supervision anxiety of teachers predicting the withdrawal from the institution sub-dimension are given on Table 6 .

Table 6: The level of how supervision anxiety predicts the withdrawal from the institution dimension

\begin{tabular}{lccccccc}
\hline Model & $\mathrm{B}$ & Standardized $\beta$ & Standard Error & $\mathrm{F}$ & $\mathrm{R}$ & $\mathrm{R} 2$ & $\mathrm{p}$ \\
\hline General supervision anxiety & -.250 & -.287 & .569 & & & & \\
Physical effects & -.142 & -.164 & .388 & & & & \\
Supervisor behaviors & -.140 & -.175 & .286 & 4.577 & .282 & .079 & $.001^{*}$ \\
Factors decreasing anxiety & -.095 & -.116 & .200 & & & & \\
Total Scale & .933 & .825 & 1.411 & & & & \\
\hline${ }^{*} \mathrm{p}<.05$ & & & & & & &
\end{tabular}

According to the multi-linear regression analysis results on Table 6 , there is a significant relationship between the sub-dimensions of the supervision anxiety scale and total scale scores along with the withdrawal from the institution score $\left(\mathrm{R}=.282, \mathrm{R}^{2}=.079\right)$, and these sub-dimension are significant predictors of teachers withdrawing from the institution they work in $(\mathrm{F}=4.577, \mathrm{p}<$ .05). These variables explain $8 \%$ of the change in the scores of teachers withdrawing from the institution they work in.

Results of the Multilinear Regression Analysis, which was conducted to examine how the level of supervision anxiety of teachers predict the factors decreasing performance sub-dimension of organizational cynicism dimension, are given on Table 7.

Table 7: The level of how supervision anxiety predicts the factors decreasing performance dimension

\begin{tabular}{lccccccc}
\hline Model & $\mathrm{B}$ & Standardized $\beta$ & Standard Error & $\mathrm{F}$ & $\mathrm{R}$ & $\mathrm{R}^{2}$ & $\mathrm{p}$ \\
\cline { 1 - 7 } General supervision anxiety & -.374 & -.343 & .688 & & & & \\
Physical effects & -.392 & -.365 & .470 & & & & \\
Supervisor behaviors & -.208 & -.207 & .346 & 7.151 & .344 & .118 & $.000^{*}$ \\
Factors decreasing anxiety & -.085 & -.083 & .243 & & & & \\
Total Scale & 1.515 & 1.081 & 1.708 & & & & \\
\hline
\end{tabular}

$*_{\mathrm{p}}<.05$

According to the multi-linear regression analysis results on Table 7, there is a significant relationship between the sub-dimensions of the supervision anxiety scale and total scale scores along with the factors decreasing teacher performance dimension $\left(\mathrm{R}=.344, \mathrm{R}^{2}=.118\right)$, and these sub-dimensions are significant predictors of the factors decreasing teacher performance subdimension $(\mathrm{F}=7.151, \mathrm{p}<.05)$. Thus, it can be stated that these variables explain $12 \%$ of the changes in the scores of the factors decreasing teacher performance sub-dimension.

Results of the Multilinear Regression Analysis regarding the level of supervision anxiety of teachers predicting the negative attitudes towards the school sub-dimension of the organizational cynicism dimension are given on Table 8 . 
Gündüz, H. B., \& Ömür, Y. E. (2016). Supervision anxiety as a predictor for organizational cynism in teachers. International Journal of Human Sciences, 13(1), 1381-1394. doi:10.14687/ijhs.v13i1.3626

Table 8: The level of how supervision anxiety predicts the negative attitudes towards the school dimension

\begin{tabular}{lccccccc}
\hline Model & $\mathrm{B}$ & Standardized $\beta$ & Standard Error & $\mathrm{F}$ & $\mathrm{R}$ & $\mathrm{R}^{2}$ & $\mathrm{p}$ \\
\hline General supervision anxiety & .299 & .297 & .641 & & & & \\
Physical effects & .577 & .581 & .437 & & & & \\
Supervisor behaviors & .129 & .140 & .323 & 7.044 & .343 & .117 & $.000^{*}$ \\
Factors decreasing anxiety & .108 & .115 & .226 & & & & \\
Total Scale & -.805 & -.621 & 1.589 & & & & \\
\hline${ }^{*} \mathrm{p}<.05$ & & & & & &
\end{tabular}

According to the multi-linear regression analysis results in Table 8, there is a significant relationship between the sub-dimensions of the supervision anxiety scale and total scale scores along with the negative attitudes of teachers towards the school dimension $\left(\mathrm{R}=.343, \mathrm{R}^{2}=.117\right)$ and these subdimensions are significant predictors of the scores of the factors decreasing performance dimension $(\mathrm{F}=7.044, \mathrm{p}<.05)$. Thus, it can be stated that these variables explain $12 \%$ of the changes in the scores of the negative attitudes of teachers towards the school sub-dimension.

Results of the Multilinear Regression Analysis regarding the level of supervision anxiety of teachers predicting the worker participation in implementing decisions sub-dimension of the organizational cynicism dimension are given on Table 9.

Table 9: The level of how supervision anxiety predicts the participation in implementing decisions dimension

\begin{tabular}{lccccccc}
\hline Model & $\mathrm{B}$ & Standardized $\beta$ & Standard Error & $\mathrm{F}$ & $\mathrm{R}$ & $\mathrm{R}^{2}$ & $\mathrm{p}$ \\
\hline General supervision anxiety & -.638 & -.696 & .591 & & & & \\
Physical effects & -.431 & -.476 & .404 & & & & \\
Supervisor behaviors & -.052 & -.062 & .297 & 4.478 & .278 & .077 & $.001 *$ \\
Factors decreasing anxiety & -.248 & -.289 & .208 & & & & \\
Total Scale & 1.532 & 1.298 & 1.298 & & & & \\
\hline
\end{tabular}

$*_{\mathrm{p}}<.05$

According to the multi-linear regression analysis results in Table 9, there is a significant relationship between the sub-dimensions of the supervision anxiety scale and total scale scores along with the scores of the teacher participation in implementing decisions dimension $\left(\mathrm{R}=.278, \mathrm{R}^{2}=.077\right)$ and these sub-dimensions are a significant predictor of the scores of the factors decreasing teacher performance sub-dimension $(\mathrm{F}=4.478, \mathrm{p}<.05)$. Thus, it can be stated that these variables explain $8 \%$ of the changes in the scores of the negative attitudes of teachers towards the school subdimension.

\section{Conclusion, Discussion and Suggestions}

This study was conducted in order to determine the level of supervision anxiety of teachers and their organizational cynicism levels, to detect the relationship between the two variables and determine how the supervision anxiety that teachers undergo predict their organizational cynicism levels. Study results suggest that teachers' anxiety levels towards supervision and their organizational cynicism levels are at a 'I'm Not Sure' level. Scores obtained from the sub- 
Gündüz, H. B., \& Ömür, Y. E. (2016). Supervision anxiety as a predictor for organizational cynism in teachers. International Journal of Human Sciences, 13(1), 1381-1394. doi:10.14687/ijhs.v13i1.3626

dimensions of the scales were analyzed and for the sub-dimensions of the supervision anxiety scale the general supervision anxiety scores were at 'I'm Not Sure' level, at 'I Disagree' level for the physical effects dimension, 'I Agree' level for the supervisor behaviors dimension and 'I Agree' level for the factors decreasing anxiety dimension.

Scores obtained from the organizational cynicism scale were observed to be 'I'm Not Sure' level for the withdrawal from the institution dimension, 'I'm Not Sure' level for the factors decreasing performance dimension, 'I Disagree' level for the negative attitudes towards the school dimensions and 'I Agree' level for the worker participation in implementing decisions dimension.

The relationship between supervision anxiety levels of teachers and their organizational cynicism levels were examined and it was observed that there is a positive, moderate level and statistically significant relationship between supervision anxiety levels and organizational cynicism levels of teachers. This can be interpreted as, as supervision anxiety levels of teachers increase so does their organizational cynicism levels.

One other finding of the study was related to the supervision anxiety levels of teachers predicting their organizational cynicism levels. The study suggests that supervision anxiety levels of teachers explain $15 \%$ of the variance related to their organizational cynicism levels. In other words, $15 \%$ of the variance explained by the organizational cynicism levels of teachers results from the anxiety levels of teachers related to supervision.

Analyses were conducted concerning how the scores of the sub-dimensions of the supervision anxiety scale of teachers and the scores of the overall scale predict the sub-dimensions of the organizational cynicism scale. According to the analyses results, $7 \%$ of the change in the scores, related to the withdrawal from the institution dimension, are explained by the overall scale score and by the sub-dimensions of the supervision anxiety scale. The same variables explain $12 \%$ of the changes that occur in the factors decreasing performance sub-dimension of organizational cynicism. $12 \%$ of the changes in the scores related to the negative attitudes towards the school dimension are explained by the overall scale score and by the sub-dimensions of the supervision anxiety scale. Finally, these variables explain $8 \%$ of the changes related to the worker participation in implementing decisions dimension.

As Mosoge and Pilane (2014) state, teachers are co-developers of education policy on the ground, act as a driving force behind the actualization of transformastion in education; the development of teachers is therefore crucial in education system. In other words, in order to be able to transform educational systems towards a better situation and improve the quality of national education systems, it is crucial to provide teachers with a stress-free environment which is thought to cause teachers to develop cynic behaviors and attitudes. It is known that organizational cynicism includes negative attitudes that an individual develops against the organization he or she is a member of and these attitudes are affected by many factors such as organizational commitment, job satisfaction, organizational culture, organizational support, organizational justice and burnout. In addition, stress that emerges due to various causes within an organization is also accepted as a source of organizational cynicism (Brandes et al., 2008; Nafei, 2013). On the other hand, because it affects one's professional status, supervision also causes teachers to be more anxious and supervision itself can be a cause of trauma for teachers. (Jeffrey \& Woods, 1998; Özmen, 2000). In addition, Yılmazoğlu-Özdoğa (2012), who stated in their study that supervision is one of the anxiety sources that teachers go through, also asserted that teachers get anxious about being negatively evaluated by the supervisor and that the principle and the supervisor are the agents that experience anxiety most when supervision is considered. Jeffrey and Woods (1996) claim that a technique and investigation based supervision is perceived by teachers as being professionally disregarded and as making the teaching profession mechanical and that as a result teachers become alien to their professions and their commitment starts to become weak. In a similar study Brimblecombe, Ormston and Shaw 
Gündüz, H. B., \& Ömür, Y. E. (2016). Supervision anxiety as a predictor for organizational cynism in teachers. International Journal of Human Sciences, 13(1), 1381-1394. doi:10.14687/ijhs.v13i1.3626

(1996) put forward that stress levels of teachers increase during a supervision and that supervision causes changes in their behaviors. In another study Brimblecombe, Ormston and Shaw (1995) stated that teachers identify the pre-supervision periods as the most stressful moments and that their level of stress increase as the supervision time becomes closer. Perryman (2007) stated that supervision causes teachers to lose their strength and control and as a result causes them to experience fear, anger and alienation due to its negative effects Bachkirova (2005) expressed that the values of teachers and supervisors are not compatible; thus, supervision damages social roles by influencing the working conditions of teachers and negatively affects the motivation of teachers.

In the educational system, along with the investigation role, supervision has a function of professionally guiding teachers and contributing to their professional development. On the other hand, a supervision which ignores the professional guidance role and is carried out on a investigation and document control basis will cause various problems for teachers. The supervision anxiety that teachers go through, the teaching profession becoming disreputable and mechanical as a result of this anxiety, the decrease in the motivation and morale of teachers, the atmosphere of conflict which emerges due to incompatible values of teachers and supervisors will certainly cause teachers to display cynical attitudes towards their organization and their profession. It won't be wrong to claim that these cynical attitudes will cause teachers to withdrawal from the institution they work in, a decrease in the performance of teachers, teachers to display negative attitudes towards their schools and a decrease in the participation of implementing decisions. Results of this study support the previous discussions stating that the supervision anxiety that teachers go through predict their levels of organizational cynicism. At this point, it is obvious that the attitudes and behaviors that supervisors display during supervision is crucial and that this is not only due to the supervisors but also due to the effects of the educational system becoming organized. Because expecting supervisors to carry out their role as a guide will increase their workload and make it difficult for them to master their counselor and nurturing functions (Bülbül and Acar, 2012). The findings of this study and the related literature suggest that the supervision system should be reconstructed by highlighting the counselor and nurturing roles of supervisors. In addition, it is crucial to train supervisors so that they would decrease the anxiety that arises in teachers during the inspection. Thus, it can be asserted that the anxiety that the supervision process and the supervisor behaviors cause and the organizational cynicism that emerges due to this anxiety will be prevented.

\section{References}

Akpınar, B. (2008). Eğitim sürecinde öğretmenlerde strese yolaçan nedenlere yönelik öğretmen görüşleri. Kastamonu Ë̈itim Dergisi, 16(2), 359-366.

Altındağ, M. (2007). İlköğretim müfettişlerinin rehberlik değerlendirme ve soruşturma roller hakkında Ankara ili öğretmen ve müfettişlerinin görüşleri. Yayımlanmamış Yüksek Lisans Tezi. Ankara Üniversitesi Eğitim Bilimleri Enstitüsü, Ankara.

Andersson, L. M. (1996). Employee cynicism: an examination using contract violation framework. Human Relations, 49(11), 1395-1418. Wiev article http://dx.doi.org/10.1177/001872679604901102

Andersson, L. M., \& Bateman, T. S. (1997). Cynicism in the Workplace: Some Causes and Effects. The Journal of Organizational Behavior, 18, 449-470. Wiev article http://dx.doi.org/10.1002/(SICI)1099-1379(199709)18:5<449::AID-JOB808>3.0.CO;2-O

Atay, K. (1995). Illköğretim müfettislerinin yeterlilikleri. Yayımlanmamış Doktora Tezi. Atatürk Üniversitesi Sosyal Bilimler Enstitüsü, Erzurum.

Bachkirova, T. (2005). Teacher stress and personal values: an exploratory study. School Psychology International, 26(3), 340-352. Wiev article http://dx.doi.org/10.1177/0143034305055978 
Gündüz, H. B., \& Ömür, Y. E. (2016). Supervision anxiety as a predictor for organizational cynism in teachers. International Journal of Human Sciences, 13(1), 1381-1394. doi:10.14687/ijhs.v13i1.3626

Beilock, S. L., Gunderson, E. A., Ramirez, G. \& Levine, S. C. (2010). Female teachers' math anxiety affects girls' math achievement. Proceedings of National Academy of Sciences, 107(5), 1860-1863. Wiev article http://dx.doi.org/10.1073/pnas.0910967107

Bernerth, J. B., Armenakis, A. A., Field, H. S. \& Walker, H. J. (2007). Justice, Cynicism, and Commitment a Study of Important Organizational Change Variables. The Journal of Applied Behavioral Science, 43(3), 309-319. Wiev article http://dx.doi.org/10.1177/0021886306296602

Bilir, M. (1992). Teftiş sisteminin yap1 ve işleyişi. Ankara Üniversitesi Ĕ̈̆tim Bilimleri Fakültesi Dergisi, 25(1), 243-256. Wiev article http://goo.gl/dMvrfI

Botwinik, R. (2007). Dealing with teacher stress. The clearing house: A Journal of Educational Strategies, Issues and Ideas, 80(6), 271-272. Wiev article http://dx.doi.org/10.3200/TCHS.80.6.271-272

Brandes, P., Castro, S., James, M. S. L., Martinez, A., Matherly, T., Ferris, G. \& Hochwarter, W. (2008) The interactive effects of job insecurity and organizational cynicism on work effort following a layoff. Journal of Leadership \& Organizational Studies, 14(3), 233- 240. Wiev article http://dx.doi.org/0.1177/1071791907311967

Brimblecombe, N., Ormston, M. \& Shaw, M. (1995). Teacher's perceptions of school inspection: a stressful experience. Cambridge Journal of Education, 25(1), 53-62. Wiev article http://dx.doi.org/10.1080/0305764950250106

Brimblecombe, N., Ormston, M. \& Shaw, M. (1996). Gender differences in teacher response to school inspection. Educational Studies, 22(1), 27-40. Wiev article http://dx.doi.org/ 10.1080/0305569960220103

Bursalığlu, Z. (2012). Okul yönetiminde yeni yapı ve davranıs. Ankara: Pegem.

Bülbül, T. \& Acar, M. (2012). A pair-wise scaling study on the missions of education supervisors in Turkey. International Journal of Human Sciences, 9(2), 623-640.

Büyüköztürk, Ş., Çokluk-Bökeoğlu, Ö. \& Köklü, N. (2008). Sosyal bilimler için istatistik. Ankara: Pegem.

Büyüköztürk, Ş., Kılıç - Çakmak, E., Akgün, Ö. E., Karadeniz, Ş. \& Demirel. F, (2012). Bilimsel araștırma yöntemleri. Ankara: Pegem.

Caspi, J. \& Reid, W. J. (2002). Educational supervision in social work. New York: Columbia University Press.

Cohen, L., Manion, L. \& Morrison, K. (2007). Research methods in education. Abingdon, Oxon: Routledge.

Dean, J. W., Brandes, P. \& Dharwadkar, R. (1998). Organizational Cynicism. Academy of Management Review, 23(2), 341-352.

Dubey, R. (2011). Occupational stress among teachers. Educational Quest, 2(2), 227-230.

Durmaz, M. (2010). Eğ̈itim sorușturmalar hakkemda ögretmen algzlar "İsatnbul ili Pendik ilçesi ömeğgi". Unpublished Master's Thesis. Maltepe Üniversitesi Sosyal Bilimler Enstitüsü, Istanbul.

Gökberk, M. (2010). FelsefeTaribi. Istanbul: Remzi.

Gündüz, Y. \& Göker, S. D. (2014). Dünya ölçeğinde eğitim denetmenlerinin iş tanımlarındaki çelişkiler ve rol çatısmaları. Abant İz̨et Baysal Üniversitesi Eğitim Fakültesi Dergisi, 14(2), 155174.

Hançerlioğlu, O. (1999). Düşünce taribi. Istanbul: Remzi. 
Gündüz, H. B., \& Ömür, Y. E. (2016). Supervision anxiety as a predictor for organizational cynism in teachers. International Journal of Human Sciences, 13(1), 1381-1394. doi:10.14687/ijhs.v13i1.3626

Helvac1, M. A. \& Çetin, A. (2012). İlköğretim okullarında görev yapan öğretmenlerin örgütsel sinizm düzeylerinin belirlenmesi (Uşak ili örneği). Turkish Studies, 7(3), 1475-1497. Wiev article http://goo.gl/A37LFa

Jeffrey, B. \& Woods, P. (1996). Feeling deprofessionalised: the social construction of emotion during an OFSTED inspection. Cambridge Journal of Education, 26(3), 32-343. Wiev article http://dx.doi.org/10.1080/0305764960260303

Jeffrey, B. \& Woods, P. (1998). Testing teachers: the effect of school inspections on primary teachers. London: Falmer Press.

Karakaya, İ., Elma, C., Kurtoğlu, S. \& Suiçmez, E. (2011). Denetim kaygısı ölçeğinin gelistirilmesi: geçerlik ve güvenirlik çalısması. Proceeding Presented at III. Uluslararası Katılımlı Eğitim Denetimi Kongresi (22-24 June, Mersin, ss.545-556). Ankara: Anı.

Karakütük, K. (2012). Eğitim Planlaması. Ankara: Elhan.

Karasar, N. (2002). Bilimsel araștırma yöntemleri: kavramlar, ilkeler, teknikler. Ankara: 3A Araşturma, Eğitim, Danışmanlık.

Kutanis, R. Ö. \& Dikili, A. (2010). Değişim boyutunda örgütlerde sinizm. In DE Özler (Ed). Örgütsel Davranısta Güncel Konular (ss. 269-285). Bursa: Ekin.

Kyriacou, C. (2001). Teacher stress: Directions for future research. Educational Review, 53(1), 27-35. Wiev article http://dx.doi.org/10.1080/00131910120033628

McCormick, J. \& Solman, R. (1992). Teachers' attributions of responsibility for occupational stress and satisfaction: An organisational perspective. Educational Studies, 18(2), 201-222. Wiev article http://dx.doi.org/10.1080/0305569920180206

Mosoge, M. J. \& Pilane, M. W. (2014). Performance management: the neglected imperative of accountability systems in education. South African Journal of Education. 34(1), 1-18. Wiev article http://dx.doi.org/10.15700/201412120947

Nafei, W. A. (2013). Examining the relationship between organizational cynicism and organizational change: a study from Egyptian context. Journal of Business Administration Research, 2(2), 1-12. Wiev article http://dx.doi.org/10.5430/jbar.v2n2p1

Özmen, F. (2000). Klinik denetim öngörüleri çerçevesinde denetçi görüşleri. Fırat Üniversitesi Sosyal Bilimler Dergisi, 10(1), 119-157. Wiev article http://goo.gl/TRE4mR

Özmen, F. \& Șahin, Ș. (2010). İlköğretim müfettişlerinin soruşturma görevini yerine getirirken karşılaştıkları sorunlar. Dicle Üniversitesi Ziya Gökalp Ë̆itim Fakültesi Dergisi, 15, 92-109. Wiev article http://goo.gl/Jf8gn6

Pelletier, K. L. \& Bligh, M. C. (2008). The aftermath of organizational corruption: employee attributions and emotional reactions. Journal of Business Ethics, 80(4), 823-844. Wiev article http://dx.doi.org/10.1007/s10551-007-9471-8

Perryman, J. (2007). Inspection and emotion. Cambridge Journal of Education, 37(2), 173-190. Wiev article http://dx.doi.org/10.1080/03057640701372418

Sağır, T. \& Oğuz, E. (2012). Öğretmenlere yönelik örgütsel sinizm ölçeğinin geliştirilmesi. International Journal of Human Sciences, 9(2), 1094-1106. Wiev article http://goo.gl/QOup92

Schulze, S. \& Steyn, T. (2007). Stressors in the professional lives of South African secondary school educators. South African Journal of Education, 27, 691-707. Wiev article http://goo.gl/tCkUhT 
Gündüz, H. B., \& Ömür, Y. E. (2016). Supervision anxiety as a predictor for organizational cynism in teachers. International Journal of Human Sciences, 13(1), 1381-1394. doi:10.14687/ijhs.v13i1.3626

Sinclair, K. E. \& Ryan, G. (1987). Teacher anxiety, teacher effectiveness, and student anxiety. Teaching and Teacher Education, 3(3), 249-253. Wiev article http://dx.doi.org/10.1016/0742051X(87)90007-2

Taymaz, H. (2012). Eğitim sisteminde teftis. Ankara: Pegem.

Tokgöz, N. \& Yılmaz, H. (2008). Örgütsel sinizm: Eskişehir ve Alanya'daki otel işletmelerinde bir uygulama. Anadolu Üniversitesi Sosyal Bilimler Dergisi, 8(2), 238-305. Wiev article https://goo.gl/SCK3cv

Turner, J. H. \& Valentine, S. R. (2001). Cynicism as a fundamental dimension of moral decision making: a scale development. Journal of Business Ethics, 34, 123-136. Wiev article http://goo.gl/OTgBqx

Urbany, J. E. (2005). Inspiration and cynicism in value statements. Journal of Business Ethics, 62, 169182. Wiev article http://dx.doi.org/10.1007/s10551-005-0188-2

Walker, A. \& Hutton, D. M. (2006). The application of psychological contract to workplace safety. Journal of Safety Research, 37(5), 433-441. Wiev article http://dx.doi.org/10.1016/j.jsr.2006.06.001

Wanous, J. P., Reichers, A. \& Austin, J. (2000). Cynicism about organizational change measurement, antecedents, and correlates. Group \& Organization Management, 25(2), $132-$ 145. Wiev article http://dx.doi.org/10.1177/1059601100252003

Wilcox, B. \& Gray, J. (1996). Inspecting Schools: holding schools to account and helping schools to improve. Buckingham: Open University Press.

Yılmazoğlu Özdoğa, B. (2012). Denetim kaygisına yönelik öğretmen ve denetmen alg1ları. Hacettepe Üniversitesi Ë̈itim Fakültesi Dergisi, 2, 98-109. Wiev article http://goo.gl/UUs2Kp

Younghusband, L. (2006). Teacher stress and working environments: Implications for teaching and learning. Nenfoundland Quarterly, 98(4), 8-11. Wiev article https://goo.gl/ulEAQP 